\title{
PERAN ZAKAT DALAM ISLAM
}

\author{
Ardianis \\ Universitas Nadlatul Ulama Sumatera Barat \\ Email : anis11ardianis@gmail.com
}

\begin{abstract}
One of the managers of zakat in the area of Government is BAZ (Badan Amil Zakat). The role of this institution provides the latest system in zakat management. this institution, must be immediately channeled to the mustahik according to the priority scale that has been compiled in the work program. The purpose of zalcat management is the increasing awareness of the community in the fulfillment and in the service of zakat worship, the increasing function and role of religious institutions in the effort to realize the welfare of society and social justice, as well as increasing the utilization and utilization of zakat.
\end{abstract}

Keywords: The role of Zakat, Zakat in Islam, Amil Zakat

Abstrak: Salah satu pengelola zakat dalam wilayah Pemerintahan adalah BAZ (Badan Amil Zakat). Peran lembaga ini memberikan sistem terbaru dalam pengelolaan zakat. lembaga ini, harus segera disalurkan kepada para mustahik sesuai dengan skala prioritas yang telah disusun dalam program kerja. Tujuan pengelolaan zakat adalah meningkatnya kesadaran masyarakat dalam penunaian dan dalam pelayanan ibadah zakat, meningkatnya fungsi dan peranan pranata keagamaan dalam upaya wewujudkan kesejahteraan masyarakat dan keadilan social, serta meningkatnya hasil guna dan daya guna zakat.

Kata Kunci : Peran Zakat, Zakat dalam Islam, Amil Zakat

\section{A. PENDAHULUAN}

Kemiskinan merupakan masalah besar dan sejak lama telah ada. Islam memandang bahwa masalah kemiskinan adalah masalah tidak terpenuhinya kebutuhan-kebutuhan primer diantaranya sandang, pangan dan papan.

Mengeluarkan zakat merupakan kewajiban bagi setiap muslim yang mampu dan telah memenuhi syarat dan ketenttuan syariat Islam. Membangun sebuah sistem pengentasan kemiskinan berbasis zakat, perlu adanya kerjasama dengan berbagai pihak untuk memaksimumkan peran zakat.

Peran merupakan proses untuk menghasilkan sesuatu yang akan dilakukan. Salah satu lembaga yang membuat masyarakat mengenai harta adalah BAZ. Kebanyakan masyarakat belum mengetahui peran Zakat yang dikelola oleh BAZ tersebut.
Potensi dan peran zakat yang ada diharapkan menjadi sarana untuk mengentaskan kemiskinan dan mendapatkan perhatian besar.

\section{B. PEMBAHASAN}

\section{Pengertian Peran}

Peran (role) merupakan proses dinamis kedudukan (status). Apabila seseorang melaksanakan hak dan kewajibannya sesuai dengan kedudukannya, maka dia menjalankan suatu peranan. Perbedaan antara kedudukan dengan peranan adalah untuk kepentingan ilmu pengetahuan. Keduanya tidak dapat dipisah-pisahkan karena yang satu tergantung pada yang lain dan sebaliknya. ${ }^{1}$

$$
\text { Levinson dalam Soekanto }
$$

mengatakan peranan mencakup tiga hal,

${ }^{1}$ Soejono Soekanto, sosiologi suatu pengantar, (Jakarta : Rajawali Pers, 2009), h. 213 
antara lain: ${ }^{2}$ Peranan meliputi normanorma yang dihubungkan dengan posisi atau tempat seseorang dalam masyarakat. Peranan dalam arti ini merupakan rangkaian peraturanperaturan yang membimbing seseorang dalam kehidupan bermasyarakat. Peranan merupakan suatu konsep tentang apa yang dapat dilakukan oleh individu dalam masyarakat sebagai organisasi. Dan peranan juga dapat dikatakan sebagai perilaku individu yang penting bagi struktur sosial masyarakat.

Peranan didefinisikan sebagai seperangkat harapan-harapan yang dikenakan kepada individu yang menempati kedudukan sosial tertentu. Peranan ditentukan oleh norma-norma dalam masyarakat, maksudnya kita diwajibkan untuk melakukan hal-hal yang diharapkan masyarakat di dalam pekerjaan kita, di dalam keluarga, dan di dalam peranan-peranan lain.

Berdasarkan pendapat para ahli diatas, peranan dapat disimpulkan bahwa peranan merupakan aspek dinamis berupa tindakan atau perilaku yang dilaksanakan oleh orang atau badan atau lembaga yang menempati atau memangku suatu posisi dalam sistem sosial.

\section{Zakat dalam Islam}

${ }^{2}$ Soejono Soekanto, sosiologi... h. 213 a. Definisi zakat

Zakat ditinjau dari segi bahasa, kata zakat merupakan kata dasar dari zakaa, yang berarti suci, berkah, tumbuh, dan terpuji. Dari segi istilah fiqih, zakat berarti sejumlah harta tertentu yang diwajibkan oleh Allah SWT diserahkan kepada orang yang berhak menerimanya. ${ }^{3}$

Zakat menurut terminologi (syar'i) adalah sejumlah harata tertentu yang diwajibkan oleh Allah SWT untuk diberikan kepada orang yang berhak menerima zakat (mustahiq) yang disebutkan dalam Al-Qur'an. Selain itu, bisa juga berarti sejumlah harta dari harta tertentu yang diberikan kepada orang yang berhak menerimanya dengan syarat-syarat tertentu. ${ }^{4}$

\section{Dasar Hukum Zakat}

Q.S At-Taubah ayat $103^{5}$ :

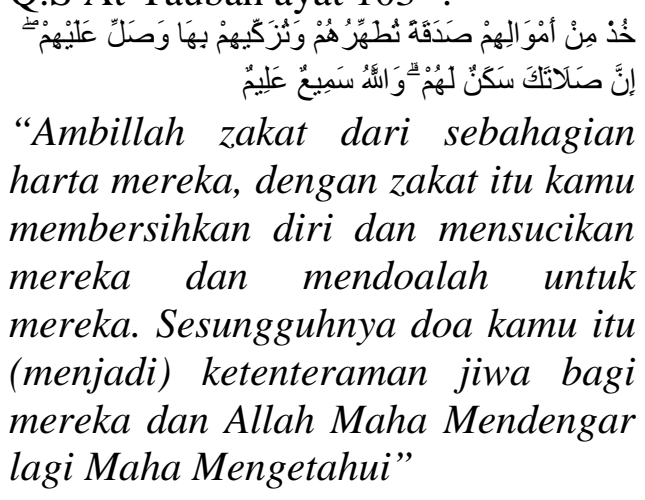

${ }^{3}$ Yusuf Qardhawi, Hukum Zakat, (Jakarta: Litera Antar Nusa dan Mizan, 1996), h. 35

${ }^{4}$ Yusuf Qardhawi, Hukum Zakat, .... h. 36

${ }^{5}$ Departemen Agama RI, Al-Hikmah Al-Qur'an dan Terjemahan, (CV. Penerbit Dipenorogo 2005), h. 203 
a. Q.S Al-Baqarah ayat $43^{6}$

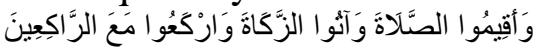

"Dan dirikanlah sholat, tunaikanlah zakat, dan ruku'lah bersama orangorang yang ruku'"

3. Syarat sah dan rukun zakat

Zakat mempunyai beberapa syarat wajib dan syarat sah. Menurut jumhur ulama, syarat wajib zakat terdiri atas: ${ }^{7}$ islam, merdeka, baligh dan berakal, harta yang dikeluarkan adalah harta yang wajib dizakati, harta yang dizakati telah mencapai nisab, harta yang dizakati adalah kepemilikan penuh, kepemilikan harta telah mencapai haul (setahun)harta tersebut bukan termasuk harta hasil hutang, harta yang akan dizakati melebihi kebutuhan pokok

Rukun zakat adalah mengeluarkan sebagian dari nisab harta yang dengan melepaskan kepemilikan terhadapnya, menjadikannya sebagai milik orang fakir atau menyerahkan harta tersebut kepada wakilnya yaitu imam atau orang yang bertugas untuk memungut zakat. ${ }^{8}$

\section{Macam-macam Zakat}

Zakat yang dikenal dalam Islam secara garis besar dikategorikan menjadi dua bentuk yaitu zakat fitrah. Zakat fitrah adalah zakat yang wajib

${ }^{6}$ Departemen Agama RI, Al-Hikmah Al-Qur'an dan Terjemahan, (CV. Penerbit Dipenorogo 2005), h. 7

${ }^{7}$ Laila, "Pengertian Zakat, Syarat Sah dan Rukun Zakat", www.pengertianzakat.com (diakses tanggal 5 Juni 2016)

${ }^{8}$ Syaikh Muhammad Abdul Malik Ar-Rahman, 1001 Masalah..., h. 12 dikeluarkan seorang muslim menjelang Idul Fitri pada bulan Ramadhan. Besar zakat ini setara dengan $2,5 \mathrm{~kg}$ makanan pokok yang ada di daerah bersangkutan dan zakat mal. Zakat mal adalah zakat kekayaan yang harus dikeluarkan dalam jangka waktu setahun sekali yang sudah memenuhi nishab, mencakup hasil perniagaan, pertanian, pertambangan, hasil laut, hasil ternak, harta temuan, emas dan perak, serta hasil kerja (profesi). ${ }^{9}$

5. Tujuan dan hakikat zakat:

Secara umum, zakat bertujuan untuk menata hubungan dua arah, yaitu hubungan vertikal dengan Tuhan dan hubungan horizontal dengan sesama manusia. ${ }^{10}$ Artinya secara vertikal, zakat sebagai ibadah dan wujud ketakwaan dan kesyukuran seorang hamba kepada Allah atas nikmat berupa harta yang diberikan Allah kepadanya serta untuk membersihkan dan mensucikan diri dan hartanya. Sedangkan secara horizontal, zakat bertujuan mewujudkan rasa keadilan sosial dan kasih sayang di antara pihak yang berkemampuan dengan pihak yang tidak mampu dan dapat memperkecil problema dan kesenjangan sosial serta ekonomi umat.

\footnotetext{
${ }^{9}$ Abdul al-Hamid, Mahmud al-Ba'Iy, Ekonomi Zakat, (Jakarta : PT. RajaGrafindo Persada, 1991) h. 3

${ }^{10}$ Asnaini, Zakat Produktif dalam Presfektif Hukum Islam, (Jogjakarta : Pustaka Pelajar. 2008), h. 42
} 
Hakikat zakat, berdasarkan dalildalil yang mewajibkannya adalah merupakan hak dan bukan merupakan pemberian atau kebaikan hati orangorang kaya semata. Dengan kata lain, zakat mencerminkan kewajiban bagi orang-orang kaya dan hak bagi golongan miskin, baik diminta ataupun tidak. ${ }^{11}$ Zakat mal adalah semua harta milik kita yang telah memenuhi syaratsyaratnya berdasarkan syariat agama Islam seperti emas, perak, binatang ternak, tumbuh-tumbuhan (buah-buahan dan biji-bjian), dan barang perniagaan. Zakat mal itu bermacam-macam.Mal artinya harta benda. Baik berupa hasil pertanian, pertenakan, perdagangan, dan lain-lain. ${ }^{12}$

6. Zakat Mal dan Macam-macamnya

Zakat mal terdiri dari beberapa jenis, antara lain: ${ }^{13}$ Zakat harta kekayaan. Zakat harta kekayaan yaitu zakat dari semua jenis harta yang sengaja disimpan baik berupa modal maupun tabungan. Harta yang dapat dikategorikan sebagai zakat ini antara lain, emas, perak, batu berharga, uang tunai, tabungan, deposito, cek, dan saham. Besarnya zakat adalah 2,5\% dari nisbahnya, yaitu senilai 94 gram emas. ${ }^{14}$

\footnotetext{
${ }^{11}$ Asnaini, Zakat Produktif... , h. 44

${ }^{12} \mathrm{http} / / /$ alimpolos.blogspot.co.id/2014/05/penger tian-cara-pelaksaan-zakat-mall.html (diakses tanggal 11 April 2015)

${ }^{13}$ Abd. Shomad, Hukum Islam...., h. 405

${ }^{14}$ Abd. Shomad, Hukum Islam...., h. 405
}

Zakat Perniagaan. Zakat perniagaan adalah zakat dari semua jenis usaha seperti perdagangan (ekspor, impor, toko, warung, kios, pabrik, industri, dan tempat usaha lainnya), jasa, pendapatan, dan keuntungan-keuntungan lain yang diperoleh dari jalan yang halal. Besar zakatnya adalah 2,5\% setiap tahun dari nisab 94 gram emas. ${ }^{15}$

Zakat binatang ternak. Zakat binatang ternak adalah zakat yang harus dikeluarkan dari kepemilikan binatang ternak, mengenai jumlah zakat dan nisabnya dapat dilihat pada tabel berikut: ${ }^{16}$

\begin{tabular}{|c|c|c|c|c|}
\hline \multirow[t]{2}{*}{ No } & \multirow{2}{*}{$\begin{array}{l}\text { Jenis } \\
\text { ternak }\end{array}$} & \multirow[t]{2}{*}{ Nisab } & \multicolumn{2}{|l|}{ Zakatnya } \\
\hline & & & Bilangan dan jenis zakat & Umur \\
\hline 1 & $\begin{array}{l}\text { Sapi dan } \\
\text { kerbaul }\end{array}$ & $\begin{array}{l}30-39 \\
40-59 \\
60-69 \\
70-\ldots\end{array}$ & $\begin{array}{l}1 \text { ekor anak sapi atau } \\
\text { seekor kerbau } \\
1 \text { ekor anak sapi atau } \\
\text { seekor kerbau } \\
2 \text { ekor anak sapi atau } \\
\text { kerbau } \\
1 \text { ekor anak sapi atau } \\
\text { seekor kerbau dan } 1 \text { ekor } \\
\text { anak sapi atau seekor } \\
\text { kerbau }\end{array}$ & $\begin{array}{l}2 \text { tahun lebih } \\
2 \text { tahun lebih } \\
1 \text { tahun lebih } \\
2 \text { tahun lebih }\end{array}$ \\
\hline 2 & $\begin{array}{l}\text { Kambing } \\
\text { atau } \\
\text { domba }\end{array}$ & $\begin{array}{l}40-120 \\
120-200 \\
201-399 \\
400-\ldots\end{array}$ & $\begin{array}{l}1 \text { ekor kambing atau } \\
1 \text { ekor domba betina } \\
2 \text { ekor kambing atau } \\
2 \text { ekor domba betina } \\
3 \text { ekor kambing atau } \\
3 \text { ekor domba betina } \\
4 \text { ekor kambing atau } \\
4 \text { ekor domba betina }\end{array}$ & $\begin{array}{l}2 \text { tahun lebih } \\
1 \text { tahun lebih } \\
2 \text { tahun lebih } \\
1 \text { tahun lebih } \\
2 \text { tahun lebih } \\
1 \text { tahun lebil } \\
2 \text { tahun lebih } \\
1 \text { tahun lebih }\end{array}$ \\
\hline
\end{tabular}

a. Zakat hasil tanaman

Zakat hasil tanaman yaitu zakat dari semua hasil pertanian, perkebunan, dan sebagainya. Besar zakatnya adalah 5\% jika dalam pengelolaan memerlukan biaya pengairan dan

\footnotetext{
${ }^{15}$ Abd. Shomad, Hukum Islam...., h. 406

${ }^{16}$ Rasyid, Sulaiman, Fiqh Islam, (Bandung: Sinar Baru Algensindo, 2012), h. 199
} 
$10 \%$ bila dalam pengelolaannya tidak memerlukan biaya pengairan, sedangkan besar nisabnya adalah senilai dengan $1.350 \mathrm{~kg}$ gabah atau $750 \mathrm{~kg}$ beras dan dikeluarkan setiap kali panen. ${ }^{17}$

b. Zakat barang hasil temuan

Zakat barang temusan yaitu zakat yang berasal dari harta yang ditemukan atau harta yang diperoleh dari cara yang tidak sengaja seperti penemuan, peninggalan, harta karun, dan sejenisnya. Besar nisabnya adalah $20 \%$ dari nilai harta tersebut dan dikeluarkan zakatnya pada saat barang itu diperoleh. ${ }^{18}$

\section{Mustahiq Zakat}

Zakat yang dikumpulkan oleh lembaga pengelola zakat, harus segera disalurkan kepada para mustahik sesuai dengan skala prioritas yang telah disusun dalam program kerja. Zakat tersebut harus disalurkan kepada para mustahik sebagaimana tergambar dalam surah at-Taubah: 60, yang uraiannya sebagai berikut:

Pertama: Fakir dan Miskin. Fakir adalah orang yang amat sengsara hidupnya, tidak mempunyai harta dan tenaga serta fasilitas yang dapat digunakan untuk memenuhi kebutuhan

\footnotetext{
${ }^{17}$ Abd. Shomad, Hukum Islam..., h. 407
}

${ }^{18}$ Abd. Shomad, Hukum Islam...., h. 407 pokoknya. ${ }^{19}$ Sedangkan miskin adalah orang yang tidak cukup penghidupannya dan dalam keadaan kekurangan. ${ }^{20}$

Kedua: Kelompok Amil (petugas zakat). Kelompok ini berhak mendapatkan bagian dari zakat, maksimal satu perdelapan atau 12,5 persen, dengan catatan bahwa petugas zakat ini memang melakukan tugastugas keamilan dengan sebaik-baiknya dan waktunya sebagaian besar atau seluruhnya untuk tugas tersebut. Menurut Yusuf Qardhawi, ada empat peran amilin (petugas zakat) yaitu mengingatkan muzakki untuk membayar zakat, menjaga perasaan para mustahiq. Karena melalui perantara amil, para mustahiq tidak perlu langsung bertemu dengan para muzakki. Lebih dari itu, cara kerja amil yang proaktif mendatangi para muzakki dan mustahiq, mereka yang kekurangan hidupnya namun tidak membiarkan diri mereka meminta-minta di jalanan, akan mendapat perhatian secara proporsional, mengontrol agar para mustahiq menerima pemberian zakat dari manamana. Karena prioritas pendistribusian zakat kepada para mustahiq harus dilaksanakan secara adil dan

${ }^{19}$ Departemen Agama RI, Panduan Pengembangan Usaha Bagi Mustahiq, (Jakarta: 2009), h. 86

${ }^{20}$ Departemen Agama RI, Fiqh Zakat, (Jakatra: 2009), h. 87 
proporsional, menentukan prioritas dan pendistribusian zakat yang produktif dan konsumtif. Hal ini diharapkan dalam satuan waktu tertentu, mustahiq dapat berubah menjadi muzakki, dengan mengembangkan zakat yang diterimanya sebagai modal usaha. ${ }^{21}$

Ketiga: Kelompok Muallaf, yaitu kelompok orang yang dianggap masih lemah imannya, karena baru masuk Islam. Dengan diberikan zakat kepada kelompok ini, diharapkan akan bertambah keimanan dan keislamannya. Mu'allafah qulubuhum, sebagaimana yang tercantum dalam AlQur'an , menurut para ulama, diperuntukkan untuk dua jenis orang, yaitu: ${ }^{22}$ Orang kafir. Orang kafir yang diharapkan masuk Islam. Zakat diberikan kepada mereka untuk mendorong agar masuk Islam sebagaimana Rasulullah Saw kepada Sofwan bin Umayyah pada saat dia masih kafir dan orang yang dikhawatirkan kejelekan atau kejahatannya dengan pemberian zakat tersebut menghentikan kejahatannya. Kemudian orang Islam. Golongan yang baru masuk Islam. Zakat yang diberikan kepada mereka dalam rangka memperkuat dan menambah keyakinan mereka terhadap Islam, orang Islam

${ }^{21}$ Abdul Hamid, Fiqh Zakat, (Curup: LP2 STAIN, 2012), h. 76

${ }^{22}$ Abdul Hamid, Fiqh Zakat, ... , h. 82 yang lemah imannya yang dikhawatirkan menjadi murtad, pemimpin dan tokoh masyarakat yang telah memeluk Islam yang masih mempunyai sahabat-sahabat orang kafir. Dengan memberikan zakat kepada mereka, dapat menarik simpati dari sahabat-sahabatnya yang masih kafir untuk memeluk Islam.

Keempat: dalam memerdekakan budak belian (riqab). Artinya bahwa zakat itu antara lain harus dipergunakan untuk membebaskan budak belian dan menghilangkan segala bentuk perbudakan. Pemberian zakat kepada budak sebagai tebusan yang akan diberikan kepada tuannya sebagai syarat pembebasan dirinya dari perbudakan merupakan salah satu cara Islam untuk menghapuskan segala bentuk perbudakan dimuka bumi.

Kelima: Kelompok Gharimin, atau kelompok orang yang berhutang karena kepentingan yang bukan maksiat dan sama sekali tidak melunasinya.

Keenam: dalam Jalan Allah SWT (fi sabilillah). Pada zaman Rasulullah saw golongan yang termasuk kategori ini adalah para sukarelawan perang yang tidak mempunyai gaji yang tetap. Tetapi berdasarkan lafaz dari sabilillah di jalan Allah SWT, sebagian ulama membolehkan memberi zakat tersebut untuk membangun masjid, lembaga pendidikan, perpustakaan, pelatihan 
para da'i, menerbitkan buku, dan lainlain.

Ketujuh: ibnu sabil, yaitu orang yang terputus bekalnya dalam perjalanan. Perjalanan disini adalah perjalanan yang bernilai ibadah. Perjalanan yang mempunyai nilai ibadah misalnya orang menuntut ilmu di negara lain, atau orang yang berdakwah di suatu daerah, kemudian apabila terputus bekalnya, dan mereka membutuhkan harta atau dana untuk sekedar mencukupi kebutuhan mereka, maka kepada mereka boleh diberikan zakat.

Disamping itu porsi zakat yang diberikan kepada golongan ini sebagai berikut: $^{23}$ biaya atau dana yang diberikan untuk pengiriiman mahasiswa untuk melanjutkan pendidikannya, penyediaan asrama murah, mengirimkan utusan ke suatu seminar atau konferensi yang membahas tentang peningkatan kehidupan beragama di tengah masyarakat.

\section{Amil Zakat}

\section{a. Amil Zakat dalam Sejarah Umat} Islam

Amil zakat dalam konteks dakwah Nabi Muhammad adalah seseorang (dari kalangan sahabat) yang menerima tugas dakwah dari Nabi Muhammad SAW untuk melakukan tindakan-tindakan tertentu sebagai amil yaitu bertugas menghimpun dan mendistribusikan harta sedekah dari muzakki kepada mustahiq. ${ }^{24}$

Nabi

Muhammad

SAW

menerima tugas keamilan berdasarkan perintah Allah swt dalam Q.S At-Taubah ayat 103:

“Ambillah zakat dari sebagian harta mereka, dengan zakat itu kamu membersihkan dan mensucikan mereka, dan mendoalah untuk mereka. Sesungguhnya doa kamu itu (menjadi) ketentraman jiwa bagi mereka. Dan Allah Maha Mendengar lagi Maha Mengetahui. ${ }^{25}$

Ayat tersebut pada awalnya adalah perintah kepada Rasul (sebagai kepada negara) untuk memungut zakat. Untuk kepentingan ini maka Rasul mengutus para sahabatnya (sebagai amil zakat) untuk memungut dan membagikan zakat, misalnya dengan mengutus Muadz bin Jabal ke Yaman.

Dalam sejarah Islam, Lembaga Zakat dikenal dengan nama Baitul Mal. Lembaga Zakat telah ada sejak Khalifah Umar bin Khattab sebagai institusi yang dimobilisir dana dan daya dari umat yang digunakan untuk upaya-upaya pembangunan

${ }^{24}$ Muhammad Sulthon, Dakwah Nabi Muhammad Dalam Bidang Sadaqat, (Jakarta: Tesis Program Doktor Pascasarjana Universitas Islam Negeri/UIN Syarif Hidayatullah, 2008), h. 235

${ }^{25}$ Departemen Agama RI, Al-Hikmah Al-Qur'an dan Terjemahan, (CV. Penerbit Dipenorogo 2005), h. 203 
meningkatkan harkat, derajat, dan martabat atau perbaikan kualitas hidup kaum dhuafa, fuqara, masakin dan umat pada umumnya berdasarkan syariah. ${ }^{26}$

Baitul Mal ini memiliki tugas dan fungsi mengelola keuangan Negara. Sumber pemasukannya berasal dari dana zakat, infak, kharaj (pajak bumi), jizyah (pajak yang dikenakan untuk non-muslim), ghanimah (harta rampasan perang), dan fai. Sedangkan penggunaannya untuk asnaf mustahik yang telah ditentukan, seperti untuk kepentingan dakwah, pendidikan, pertahanan, kesejahteraan sosial, dan pembuatan struktur. $^{27}$

Kode etik yang diberikan Nabi Muhammad SAW kepada amil zakat untuk melaksanakan tugasnya sebagai berikut. Pertama, amil harus menahan diri dari mengambil dari yang terbaik atau yang terpilih dari muzakki. Kedua, amil tidak boleh berbuat tidak adil atau memaksa. Ketiga, amil tidak boleh korupsi atau meminta tambahan sedikitpun. Keempat, amillah yang harus mendatangi muzakki bukan muzakki yang diminta untuk mendatangi amil guna menyerahkan harta sedekah. ${ }^{28}$

Masa Nabi Muhammad SAW, suatu tempat yang difungsikan untuk kepentingan tersebut adalah masjid. Pada masa Nabi Muhammad SAW masjid bukan hanya sebagai tempat ibadah, akan tetapi juga tempat bertemu dan berbagi pendapat dengan orang-orang. Di masjid pula perintah-perintah resmi dikeluarkan. Masjid digunakan sebagai kantor pusat Negara, tempat tinggal Nabi Muhammad sekaligus dipakai untuk melaksanakan fungsi baitul mal, yaitu mengumpulkan harta Negara yang pantas dikumpulkan di tempat itu dan membelanjakannya sesuai syariat. $^{29}$

Awal pemerintahan Islam, ketika pemasukan Negara tidak terlalu banyak, Nabi Muhammad mengumpulkan harta Negara itu untuk kemudian segara mendistribusikannya kepada masyarakat tanpa ada sisa. Pengaturan baitul mal tersebut, yakni pengurusan keuangan untuk sektor publik maupun sektor lainnya tidak mempunyai bentuk yang tetap, tetapi sangat fleksibel dan tidak terlalu birokratis. Pendapatan Negara dari

\footnotetext{
${ }^{26}$ Asnaini, Zakat Produktif... , h. 64

${ }^{27}$ Gustian Juanda, Pelaporan Zakat Pengurang Pajak dan Penghasilan, (Jakarta: RajaGrafindo Persada, 2006), h. 2
}

${ }^{28}$ Muhammad Sulthon, Dakwah Nabi..., h. 262

${ }^{29}$ Adiwarman Karim, Sejarah Pemikiran Ekonomi Islam, (Jakarta: Gema Insani, 2001), h.37 
sumber-sumber yang ada seperti hasil rampasan perang dan harta hasil zakat yang dipungut dari para muzakki segera dibagikan kepada yang berhak. Mekanisme pembelanjaan dari pendapatan Negara pada waktu itu berada pada tahap mudah, sederhana, dan tidak rumit, sehingga kehadiran baitul mal tidak Nampak menonjol. Keadaan demikian tetap berjalan sampai pemerintahan berada di tangan Khalifah Abu Bakar. ${ }^{30}$

Pada masa Khalifah Umar bin Khattab, wilayah pemerintahan Islam berkembang semakin meluas. Negara menguasai wilayah baru dan memperoleh pendapatan seperti hasil perang yang melebihi kebutuhan belanja Negara sehingga ada kelebihan untuk disimpan. Pada masa Umar itulah ada perubahan pada system administrasi baitul mal. Akibat penaklukan muslim, perluasan wilayah Negara dan bertambahnya pendapatan muslim seperti dari pajak tanah taklukan. Umar bin Khattab mendirikan baitul mal lokal di berbagai provinsi. Sejak saat itu, system administrasi dikembangkan dan Negara Islam memiliki baitul mal di pusat dan beberapa di lokal. Institusi baitul mal

${ }^{30}$ Muhammad Sulthon, Dakwah Nabi..., h. 274 memerankan peran semakin aktif dalam bidang keuangan dan administrasi, sejalan dengan pemasukan Negara yang semakin bertambah. $^{31}$

Pengertian baitul mal saat ini, tidak lagi seperti di zaman Rasulullah SAW dan para sahabat. Akan tetapi, mengalami penyempitan, yaitu hanya sebagai lembaga yang menghimpun dan menyalurkan dana-dana zakat, infak, sedakah dan wakaf, atau lebih dikenal sebagai organisasi pengelola zakat. $^{32}$

\section{b. Organisasi Pengelola Zakat di}

\section{Indonesia}

Organisasi pengelola zakat di Indonesia diatur oleh beberapa peraturan perundang-undangan, yaitu UU No. 38 Tahun 1999 tentang Pengelolaan Zakat, Keputusan Menteri Agama No. 581 Tahun 1999 tentang Pelaksanaan UU No. 38 Tahun 1999, dan Keputusan Direktur Jenderal Bimbingan Masyarakat Islam dan Urusan Haji No. D/291 Tahun 2000 tentang Pedoman Teknis Pengelolaan Zakat. ${ }^{33}$

Lembaga zakat di Indonesia telah ada dan tumbuh begitu lama, tapi belum dikembangkan secara

${ }^{31}$ Adiwarman Karim, Ekonomi Islam, (Jakarta: Gema Insani, 2001), h. 192

${ }^{32}$ Gustian Juanda, Pelaporan Zakat... , h. 3

${ }^{33}$ Gustian Juanda, P elaporan Zakat..., h. 3 
professional. Lembaga zakat dalam perjalanannya mengalami beberapa permasalahan, yang tidak dapat dipisahkan dari kehidupan umat Islam sehari-hari. Permasalahan tersebut adalah adanya krisis kepercayaan umat terhadap segala macam bentuk usaha penghimpun dana umat karena terjadi penyelewengan atau penyalahgunaan akibat sistem kontrol dan pelaporan yang lemah. Dampaknya orang lebih memilih membayar langsung kepada mustahiq dari pada melalui lembaga zakat, adanya pola pandangan pelaksanaan zakat yang umumnya lebih antusias pada zakat fitrah saja yakni menjelang Idul Fitri, tidak seimbangnya jumlah dana yang terhimpun dibandingkan dengan kebutuhan umat, sehingga dana terkumpul cenderung digunakan hanya untuk kegiatan konsumtif dan tak ada bagian untuk produktif. Hal ini juga karena tidak semua muzakki berzakat melalui lembaga zakat, terdapat semacam kejemuan di kalangan muzakki, dimana dalam periode waktu yang relatif pendek harus dihadapkan dengan berbagai lembaga penghimpun dana, adanya kekhawatiran politis sebagai akibat kasus penggunaan dana umat tersebut untuk tujuan-tujuan politik praktis. ${ }^{34}$

Peraturan perundang-undangan mengakui adanya dua jenis organisasi pengelolaan zakat, yaitu: Lembaga Amil Zakat, yaitu organisasi pengelola zakat yang sepenuhnya dibentuk oleh masyarakat, dan dikukuhkan oleh pemerintah. Badan Amil Zakat, yaitu organisasi pengelola zakat yang dibentuk oleh pemerintah.

Badan Amil Zakat memiliki sebagai berikut: Pertama, Nasional yang dibentuk oleh Presiden atas usul Menteri Agama. Kedua, Daerah Provinsi, dibentuk oleh Gubernur atas usul Kepala Kantor Wilayah Agama Daerah. Ketiga, Daerah Kabupaten atau Kota, dibentuk oleh Bupati atau Walikota atas usul Kepala Kntor Departemen Agama Kabupaten atau Kota. Keempat, Kecamatan dibentuk oleh Camat atas usul Kepala Kantor Urusan Agama Kecamatan.

Struktur organisasi BAZ terdiri dari tiga bagian, yaitu Dewan Pertimbangan, Komisi Pengawas, dan Badan Pelaksana. Kepengurusan BAZ tersebut ditetapkan setelah melalui tahapan yaitu membentuk tim penyeleksi yang terdiri atas unsur 
ulama, cendekia, tenaga professional, praktisis pengelola zakat, Lemaga Swadaya Masyarakat terkait, dan pemerintah. Lalu, menyusun kriteria calon pengurus. Kemudian, mempublikasikan rencana pembentukan BAZ secara luas kepada masyarakat. Selanjutnya, melakukan penyeleksian terhadap calon pengurus sesuai dengan keahliannya. Calon pengurus terpilih kemudian diusulkan untuk ditetpkan secara resmi. ${ }^{35}$

Beberapa kriteria yang harus dimiliki oleh pengurus BAZ antara lain, memiliki sifat amanah, mempunyai visi dan misi, berdedikasi, professional, berintegritas tinggi, mempunyai program kerja, dan paham fiqih zakat.

BAZ dibentuk oleh pemerintah, tetapi sejak awal proses pembentukan sampai kepengurusannya harus melibatkan unsur masyarakat. Menurut peraturan hanya posisi sekretaris saja yang berasal dari pejabat Departemen Agama.

Fungsi dari masing-masing struktur di BAZ adalah sebagai berikut: Dewan Pertimbangan berfungsi memberikan pertimbangan, fatwa, saran, dan rekomendasi tentang pengembangan hukum dan pemahaman mengenai pengelolaan zakat. Komisi Pengawas memiliki fungsi melaksanakan pengawasan atau internal atas operasional kegiatan yang dilaksanakan Badan Pelaksana. Badan Pelaksana sendiri memiliki fungsi melaksanakan kebijakan BAZ dalam program pengumpulan, penyaluran, dan pendayagunaan zakat.

BAZ mempunyai kewajiban yang harus dilaksanakan, yaitu segera melakukan kegiatan sesuai program kerja yang telah dibuat. Menyusun laporan tahunan termasuk laporan keuangan. Mempublikasikan laporan keuangan tahunan yang telah diaudit oleh akuntan publik atau lembaga pengawas pemerintah yang berwenang melalui media massa sesuai dengan tingkatannya, selambat-lambatnya enam bulan setalah tahun buku terakhir. Menyerahkan laporan tahunan tersebut kepada pemerintah dan Dewan Perwakilan Rakyat sesuai dengan tingkatannya. Merencanakan kegiatan tahunan. Dan mengutamakan pendistribusian dan pendayagunaan dana zakat yang 
diperoleh di daerah masing-masing sesuai dengan tingkatannya. ${ }^{36}$

\section{c. Definisi Amil Zakat}

Menurut Imam Syafi'i amilun adalah orang-orang yang diangkat untuk memungut zakat dari pemilikpemiliknya. ${ }^{37}$ Dari pengertian di atas maka amil ialah orang-orang yang bertugas mengumpulkan zakat.

Menurut Qardhawi, 'amilun adalah semua orang yang bekerja dalam perlengkapan administrasi urusan zakat, baik urusan pengumpulan, penyimpanan, pencatatan, perhitungan, maupun mencatat keluar masuk surat. $^{38}$ Menurut Imam Syafi'I, 'amilun adalah orang-orang yang diangkat untuk memungut zakat dari pemilikpemiliknya. ${ }^{39}$ Amil zakat adalah orang-orang yang ditugasi imam, kepala pemerintahan atau wakilnya untuk mengumpulkan zakat, jadi pemungut-pemungut zakat, termasuk para penyimpan, pengembalapengembala ternak, dan yang mengurus administrasinya. ${ }^{40}$ Dari pengertian di atas, amil zakat adalah orang-orang yang bertugas mengumpulkan zakat.

${ }^{36}$ Gustian Juanda, P elaporan Zakat..., h. 4-6

${ }^{37}$ Asnaini, Zakat Dalam Prespektif Hukum

Islam, Yogyakarta: Pustaka Pelajar, 2008, hlm. 54

${ }^{38}$ Yusuf Qardhawi, Hukum Zakat, ... h. 545

${ }^{39}$ Asnaini, Zakat Produktif... h. 54

${ }^{40}$ Sayyid Sabiq, Fiqh sunnah jilid 3, (Bandung: Al-Ma'aif, 2006), h. 91

\section{d. Syarat-syarat Amil Zakat}

Amil zakat adalah orang-orang yang terlibat atau ikut aktif dalam kegiatan pelaksanaan zakat yang dimulai sejak dari mengumpulkan atau mengambil zakat dari para muzakki sampai membagikannya kepada para mustahiq. Orang-orang yang ditunjuk sebagai amil zakat harus mempunyai beberapa syarat, yaitu beragama Islam. Zakat bagi kaum muslimin mempunyai nilai ibadah disamping nilai sosial. Zakat merupakan termasuk salah satu rukun Islam, yaitu rukun yang ketiga dan zakat merupakan bentuk manifestasi keimanan dan ketakwaan seorang muslim kepada ajaran Islam, sehingga kepengurusannya pun tidak mungkin diserahkan kepada selain muslim yang notabene mereka tidak mengimani Islam. ${ }^{41}$ Mukallaf, yaitu orang dewasa dan sehat akal pikirannya. ${ }^{42}$ Memiliki sifat amanah/jujur. Kejujuran dan amanah adalah dua hal yang harus dimiliki oleh seorang petugas zakat. Karena mereka sehari-harinya akan berhubungan dengan dana zakat yang tidak sedikit. Kejujuran dan amanah juga akan sangat

${ }^{41}$ Septy Wulandari, "Amil Zakat dalam Pandangan Islam", www.amilzakat.com (diakses pada tanggal 5 Juni 2016)

${ }^{42}$ Septy Wulandari, "Amil Zakat dalam Pandangan Islam", www.amilzakat.com (diakses pada tanggal 5 Juni 2016) 
mempengaruhi

kepercayaan

masyarakat.

Jika dihadapan

masyarakat para petugas zakat memperlihatkan sifat jujur dan amanah, maka masyarakat akan memberikan kepercayaannya kepada lembaga pengelolaan zakat dimana petugas zakat itu berada, yang dampaknya akan semakin tenang mereka untuk menyalurkan zakatnya kepada lembaga itu, begitupun sebaliknya. ${ }^{43}$ Memiliki kemampuan untuk melaksanakan tugas dengan sebaik-baiknya.

Seorang petugas juga harus mampu melaksanakan tugas, dalam artian kompeten dengan tugas yang diembannya baik dari segi fisik maupun keilmuan dan pengetahuan. ${ }^{44}$ Mengerti dan memahami hukum-hukum zakat sehingga ia mampu melakukan sosialisasi kepada masyarakat yang berkaitan dengan masalah zakat. ${ }^{45}$

Para ulama mensyaratkan harus memahami hukum-hukum zakat, khususnya petugas yang secara bergelut dengan zakat, karena mereka yang nantinya akan mengambil, mencatat, dan

\footnotetext{
${ }^{43}$ Septy Wulandari, "Amil Zakat dalam Pandangan Islam", www.amilzakat.com (diakses pada tanggal 5 Juni 2016)

${ }^{44}$ Septy Wulandari, "Amil Zakat dalam Pandangan Islam", www.amilzakat.com (diakses pada tanggal 5 Juni 2016)

${ }^{45}$ Yusuf Qardhawi, Hukum Zakat, ... h. 551
}

menyalurkan kepada mustahiq, dan semua itu membutuhkan kepada pengetahuan tentang zakat supaya tidak salah dalam perhitungan dan salah dalam penyaluran.

Adapun petugas yang secara tidak langsung bergelut dengan zakat, maka tidak disyaratkan untuk mengetahui hukum-hukum zakat. Tapi alangkah baiknya merekapun mengetahui hukum-hukum standar minimal zakat, karena bagaimanapun mensyaratkan tetap melihat petugas tersebut adalah petugas zakat. Pemahaman tentang hukum-hukum zakat bagi seorang petugas di sebuah lembaga pengelola zakat akan sangat mempengaruhi kepercayaan masyarakat terhadap lembaga tersebut.

\section{e. Tugas Amil Zakat}

Menurut Undang-Undang No. 23 Tahun 2011 pasal 7, dalam melaksanakan tugasnya, BAZNAS menyelenggarakan fungsi: ${ }^{46}$ perencanaan pengumpulan, pendistribusian, dan pendayagunaan zakat, pelaksanaan pengumpulan, pendistribusian, dan pendayagunaan zakat, pengendalian pengumpulan, pendistribusian, dan pendayagunaan zakat, pelaporan dan

${ }^{46}$ Undang-Undang Republik Indonesia No. 23 Tahun 2011 tentang Pengelolaan zakat 
pertanggungjawaban pelaksanaan pengelolaan zakat.

Tujuan pengelolaan zakat adalah meningkatnya kesadaran masyarakat dalam penunaian dan dalam pelayanan ibadah zakat, meningkatnya fungsi dan peranan pranata keagamaan dalam upaya wewujudkan kesejahteraan masyarakat dan keadilan social, serta meningkatnya hasil guna dan daya guna zakat. $^{47}$

Undang-undang tentang pengelolaan zakat juga mencakup pengelolaan infak shadaqah, hibah, wasiat, waris, dan kafarat dengan perencanaan pengorganisasian, pelaksanaan, dan pengawasan agar menjadi pedoman bagi muzakki dan mustahiq, baik perseorangan maupun badan hukum dan badan usaha. ${ }^{48}$

Untuk menjamin pengelolaan zakat sebagai amanah agama, dalam undang-undang ini ditemukan ada unsur pertimbangan dan unsur pengawasan yang terdiri atas ulama, kaum cendikia, tokoh masyarakat, dan pemerintah serta adanya sanksi hokum terhadap pengelola. ${ }^{49}$

Dengan ditetapkannya undangundang tentang pengelolaan zakat

\footnotetext{
${ }^{47}$ Departemen Agama RI, Peraturan Perundang-Undangan Pengelolaan Zakat, h.14

${ }^{48}$ Departemen Agama RI, Peraturan Perundang-Undangan Pengelolaan Zakat, h.14

${ }^{49}$ Departemen Agama RI, Petunjuk Pelaksanaan Pemberdayaan Zakat, h.3
}

diharapkan dapat meningkatkan kesadaran muzakki untuk menunaikan kewajiban zakat dalam rangka mensucikan harta yang dimilikinya, mengangkat derajat mustahiq, dan meningkatnya keprofesionalan pengelola zakat, yang semuanya untuk mendapatkan ridha Allah swt.

Selain tugas-tugas di atas,secara garis besarnya tugas Amil Zakat meliputi: ${ }^{50}$ mencatat nama-nama, menghitung besarnya harta zakat yang akan dipungut atau diambil dari muzakki, mengumpulkan atau mengambil harta zakat dari muzakki, mendoakan orang yang membayar zakat, menyimpan, menjaga, dan memelihara harta zakat sebelum dibagikan kepada mustahiq zakat, mencatat nama-nama mustahiq zakat, menentukan prioritas mustahiq zakat, menentukan besarnya zakat yang akan dibagikan kepada para mustahiq zakat, membagikan harta zakat kepada para mustahiq zakat, mencatat atau mengadministrasikan semua kegiatan pengelola tersebut, serta mempertanggungjawabkannya sesuai dengan ketentuan yang berlaku, mendayagunakan harta

${ }^{50}$ Suparman Usman, Azas-azas Dan Pengantar Studi Hukum Islam Dalam Tata Hukum Indonesia, (Jakarta: gaya Media Pratama, 2002), h. 162-163 
zakat dan mengembangkan harta zakat.

Posisi ini semakin kuat ketika Presiden RI mengeluarkan Keputusan Nomor 8 Tahun 2001 tentang dibentukknya Badan Amil Zakat Nasional (BAZNAS). Dalam hal ini, BAZNAS memiliki tugas pokok untuk merealisasikan misi BAZNAS, sebagai berikut: $^{51}$ meningkatkan kesadaran umat untuk berzakat, mengerahkan masyarakat mencapai kesejahteraan baik fisik maupun non fisik melalui pendayagunaan zakat, meningkatkan status mustahik menjadi muzakki melalui pemulihan, peningkatan kualitas SDM, dan pengembangan ekonomi masyarakat, mengembangkan budaya "member lebih baik dari menerima", mengembangkan manajemen yang amanah, professional, dan transparan dalam mengelola zakat, menjangkau muzakki dan mustahik seluasluasnya, memperkuat jaringan antar organisasi pengelola zakat.

\section{KESIMPULAN}

Salah satu pengelola zakat dalam wilayah Pemerintahan adalah BAZ (Badan Amil Zakat). Peran lembaga ini memberikan sistem terbaru dalam pengelolaan zakat. lembaga ini, harus segera disalurkan kepada para mustahik sesuai dengan skala prioritas yang telah disusun dalam program kerja.

Tujuan pengelolaan zakat adalah meningkatnya kesadaran masyarakat dalam penunaian dan dalam pelayanan ibadah zakat, meningkatnya fungsi dan peranan pranata keagamaan dalam upaya wewujudkan kesejahteraan masyarakat dan keadilan social, serta meningkatnya hasil guna dan daya guna zakat.

\section{DAFTAR PUSTAKA}

Abdul al-Hamid, Mahmud al-Ba'Iy, Ekonomi Zakat, Jakarta : PT. RajaGrafindo Persada, 1991

Abdul Hamid, Fiqh Zakat, Curup: LP2 STAIN, 2012

Adiwarman Karim, Ekonomi Islam, Jakarta: Gema Insani, 2001

Adiwarman Karim, Sejarah Pemikiran Ekonomi Islam, Jakarta: Gema Insani, 2001

Asnaini, Zakat Dalam Prespektif Hukum Islam, Yogyakarta: Pustaka Pelajar, 2008

Asnaini, Zakat Produktif dalam Presfektif Hukum Islam, Jogjakarta : Pustaka Pelajar. 2008

Departemen Agama RI, Al-Hikmah Al-Qur'an dan Terjemahan, CV. Penerbit Dipenorogo 2005

Didin Hafiduddin, Zakat Dalam Perekonomian Modern, Jakarta: Gema Insani Press 2002

Gustian Juanda, Pelaporan Zakat Pengurang Pajak dan Penghasilan, Jakarta: RajaGrafindo Persada, 2006

Laila, "Pengertian Zakat, Syarat Sah dan Rukun

Zakat",

${ }^{51}$ Mujahidin, Akhmad, Ekonomi Islam, (Jakarta: RajaGrafindo Persada), 2007, h. 72 
www.pengertianzakat.com (diakses tanggal 5 Juni 2016)

Muhammad Sulthon, Dakwah Nabi Muhammad Dalam Bidang Sadaqat, Jakarta: Tesis Program Doktor Pascasarjana Universitas Islam Negeri/UIN Syarif Hidayatullah, 2008

Mujahidin, Akhmad, Ekonomi Islam, Jakarta: RajaGrafindo Persada, 2007

Rasyid, Sulaiman, Fiqh Islam, Bandung: Sinar Baru Algensindo, 2012

Sayyid Sabiq, Fiqh sunnah jilid 3, Bandung: Al-Ma'aif, 2006

Septy Wulandari, "Amil Zakat dalam Pandangan Islam", www.amilzakat.com (diakses pada tanggal 5 Juni 2016)

Soejono Soekanto, sosiologi suatu pengantar,(Jakarta : Rajawali Pers, 2009

Suparman Usman, Azas-azas Dan Pengantar Studi Hukum Islam Dalam Tata Hukum Indonesia, Jakarta: gaya Media Pratama, 2002

Undang-Undang Republik Indonesia No. 23 Tahun 2011 tentang Pengelolaan zakat

Yusuf Qardhawi, Hukum Zakat, Jakarta: Litera Antar Nusa dan Mizan, 1996 